\title{
Analysis Of Factors Affecting Performance Of Employees In Office Of Public Work And Spatial Planning Of Padang City
}

\author{
Merry Darmasari \\ Master of Management, STIE "KBP ", \\ JL Khatib Sulaiman No. 61 Lolong Belanti, \\ Padang Utara 25136, West Sumatra, Indonesia \\ Heryanto \\ Lecturer in Management Master Program, STIE “KBP”, \\ JL Khatib Sulaiman No. 61 Lolong Belanti, \\ Padang Utara 25136, West Sumatra, Indonesia
}

\begin{abstract}
This study aims to analyze the factors that influence the performance of employees of the public works and spatial planning office of Padang city. Sample selection was done by purposive sampling with a total sample of 98 employees. The data analysis method used in this study is path analysis method, classic assumption test and hypothesis test. Testing in this study was carried out using the SPSS 21 computer program. The variables in this study consisted of additional variables of employee income, work environment, work motivation and employee performance. Testing the first hypothesis shows the results that additional employee income has a positive and significant influence on work motivation, testing the second hypothesis shows the results of the work environment have a positive and significant effect on work motivation, testing the third hypothesis shows that the additional employee income has no significant effect on employee performance, testing the fourth hypothesis shows that the work environment has an influence and is not significant on employee performance, testing the fifth hypothesis shows that work motivation has an influence and is significant on employee performance, the sixth hypothesis testing shows that the additional income of the employee has a significant effect on work motivation and has no impact on employee performance, testing the seventh hypothesis shows that the work environment has a significant and significant influence on work motivation and does not affect employee performance. Finally, the authors suggest the next researcher to further expand the scope of the sample and add variables or other factors that can affect employee performance.
\end{abstract}

Keywords: additional employee income, work environment, work motivation, employee performance

\section{INTODUCTION}

Civil Servants are employees who have fulfilled the conditions stipulated in the applicable laws and regulations, appointed by authorized officials and entrusted with duties in a state office or entrusted with other state duties determined under a statutory regulation and paid according to applicable regulations. Employees in this case are planners, implementers and controllers who will carry out every policy that has been set. This requires a good work environment certainly that can be felt by each employee because if the employee's work environment gets better then the employee is motivated and the performance of the employee will also be higher and vice versa. If the employee's work environment is not good then the employee is not motivated and the performance of the employee will also be low. Added by giving motivation and providing benefits that are in accordance with the performance of the employee. 
Assessment of employee performance is done certainly by looking at the achievement of targets set at the beginning of the planning year to improve welfare. Performance can be interpreted as a result of one's efforts achieved by the ability and manufacture in certain situations. Employee performance is a description of the level of achievement of the goals or objectives of government employees as a description of the vision, mission and strategic plans of government employees that indicate the level of success and failure in the implementation of activities in accordance with the programs and policies that have been set.

One public organization that emphasizes the welfare of the community is the public works office and th spatial planning of Padang city. As stated in the government regulation of the Republic of Indonesia number 41 of 2007 concerning "regional device organizations" that the regional service is an element of regional autonomy where the development of autonomy in the regions is carried out by observing the principles of democracy, community participation, equity and fairness in the development of regional government. One aspect of regional government that must be regulated carefully is the issue of regional financial management and regional budgets. Allowances are one element of economic classification for expenditure, which is included in employee expenditure.

The application of benefits is one of the ways in which the government develops regional development. Benefits are one of the important elements in work relations and achievement of development. In this case, namely Additional Employee Income (AEI). The minister of home affairs regulation number 59 of 2007 concerning regional financial management specifically stated in article 39, which states that regional governments can provide additional income to civil servants based on objective considerations by paying attention to regional financial capacity and obtaining approval from the regional house of representatives. Additional income is intended to increase the welfare of civil servants based on workload, place of duty, working conditions, professional scarcity or work performance. In addition, based on government regulation No. 58 of 2005 concerning regional financial management article 63 paragraph (2) and regulation of the minister of home affairs No. 13 of 2006 concerning guidelines for regional financial management which have been amended by the minister of home affairs regulation No. 59 of 2007 and the minister of home affairs regulationi No. 21 of 2011 concerning the second amendment to the minister of home affairs regulation No. 13 of 2006, states that civil servants can be given additional income according to regional financial capacity.

Providing additional income as part of efforts to prevent corruption in the government bureaucracy and can be a motivation to improve the performance of the apparatus. Giving additional income must be in line with improving employee performance. Therefore, all employees must improve their work ability, work discipline, work performance, collaboration among employees, and increase commitment and motivation.

Additional income is also given to employees in the public works and spatial planning office of Padang City who are in charge of carrying out government affairs in the field of public works and spatial planning which is the authority of the region, and carrying out co-administration tasks assigned to the regions.

Additional income takes into account the performance of employees assessed in one. Based on government regulation Number 46 of 2011, employee performance evaluation consists of two elements, namely Employee Work Target (EWT) and employee behavior. The target of performance achievement according to the work target in EWT made by civil servants, is expected to create civil servants whose performance is good, motivated and have good 
behavior in terms of service, integrity, commitment, discipline, cooperation and leadership. Because so far there has been an opinion in the community that civil servants are always associated with underperforming, low motivation and very lack of discipline.

In providing Employee Income Supplement (EIS), employees are required to fill out Employee Work Goals (EWG) online to assess employee performance on a regular basis by reporting every month, but this performance assessment also experiences quite complex constraints including employees who stutter technology, employee performance that has not been in accordance with the performance of the city, less objective assessment of superiors to employees so that the assessment of employees is not in accordance with its performance, and the absence of measurable employee work targets. Even though the government has provided additional income for civil servants in accordance with the decree of the Mayor of Padang No 501 of 2016 deciding to stipulate: Additional income as referred to in the dictum is paid in accordance with the achievement of the performance of civil servants every month.

As well as the decision of the Mayor of Padang No. 1 of 2018 concerning the amount of additional income for civil servants decides, stipulates: The additional income as referred to in the dictum is paid in accordance with the performance of civil servants every month. As well as when this decision came into force, the decision of the Mayor of Padang No. 349A in 2017 concerning the amount of additional income for civil servants was revoked and declared invalid.

However, in its implementation, many employees do not receive additional employee income in accordance with a predetermined amount because in practice performance appraisal is not really carried out by the party that should be due to lack of work ability possessed by some employees who are not in accordance with their capabilities, especially in the field technology where in EWG reporting every month employees use technology media, namely computers because of this limitation many assessments are not in accordance with reality and a nonconducive work environment also greatly influences employee motivation and performance.

According to Dhermawan, Sudibya \& Utama, (2012) the work environment is everything that exists around the workers and that can affect him in carrying out the tasks that are charged. Work environment factors can be in the form of physical conditions of the office which include lighting, air temperature, etc. that can improve the conducive atmosphere and morale and influence employee performance. According to Mangkunegara (2006) the work environment includes clear job descriptions, adequate authority, challenging work targets, communication patterns, harmonious work relations, dynamic work climate, career opportunities, and adequate work facilities. An unsatisfactory work environment can reduce morale and ultimately reduce employee work productivity (Dhermawan et al., 2012).

\section{Additional Employee Income (AEI)}

\section{LITERATURE REVIEW}

Additional employee income (AEI) is an addition given to civil servants and candidate of the civil servants that are associated with attendance and performance assessments. The income of civil servants consists of salaries, allowances and honorariums, among others in the form of overtime money, but other incentives in the form of Additional Income Allowances for civil servants in government regulation No. 58 of 2005 and minister of home Affairs regulation number 13 in 2006 referred to Additional Employee Income are additional income provided in the context of increasing employee welfare based on workload criteria, assignment, working conditions and work performance 
The performance indicators in the provision of employee income in the Mayor of Padang decree No. 49 of 2017 concerning amendments to the mayor's regulation of Padang Number 12 of 2017 concerning Additional income for civil servants that additional income is given to all civil servants based on regional financial capabilities with criteria:

1. The workload of civil servants to complete tasks that are considered to exceed normal workloads

2. The working conditions of civil servants in carrying out their duties are in a high-risk environment.

3. Additional income based on professional scarcity.

4. Additional income based on the place of duty

5. Additional income is based on other objective considerations.

\section{Work Environment}

The work environment is something that is around the workers and that affects themselves in carrying out the tasks that are charged (Nitisemito, 1992). The company should be able to reflect the conditions that support cooperation between supervisors, subordinates and those with the same position status in the company. Conditions that should be created are a family atmosphere, good communication and self-control. The work environment can be interpreted as influencing forces, both directly and indirectly towards the performance of an organization or company (Terry, 2006).

The work environment indicators proposed by Nitisemito (1992) are as follows:

\section{Work atmosphere}

Work atmosphere is a condition that exists around employees who are doing work that can affect the implementation of the work itself. This work atmosphere will include workplaces, work facilities and aids, success, lighting, tranquility including work relations between people in the place (Saydam, 1996).

\section{Relations with coworkers}

Relationships with coworkers are harmonious relationships with coworkers and without mutual intrigue between fellow workers. One of the factors that can influence employees staying in one organization is the existence of a harmonious relationship between coworkers.

\section{Relationship between subordinates and leaders}

The relationship between employees and leaders is the relationship with employees who are good and harmonious with the leadership of the workplace. A good and harmonious relationship with the leadership of the workplace is an important factor that can affect employee performance.

\section{Availability of work facilities}

It is intended that the equipment used to support the smooth / complete work. The availability of complete work facilities, although not new is one of the supporting processes in work.

\section{Employee Performance}

According to Mangkunegara (2005) performance is defined as the work results in quality and quantity achieved by an employee in carrying out his duties in accordance with the responsibilities given to him.

T.R. Mitchell (1978) in Sedarmayanti (2001) also states that performance includes several aspects, namely: 
1. Quality of Work, namely the quality of work produced can be satisfying for its users or not so that it is used as a work standard.

2. Promptness, namely the speed of work measured by the level of time, namely the speed of work measured by the level of time so that employees are required to work fast in achieving satisfaction and and improving performance.

3. Initiative namely the level of initiative and responsibility for work.

4. Capability namely reliability in completing tasks and knowledge of work.

5. Communication namely employees are able to communicate well between employees or with their leaders.

\section{Motivation}

Motivation can be defined as a condition in someone who encourages, activates or moves and which directs behavior towards the goal (Pujadi, 2007). According to Uno in Nursalam (2008) motivation can be interpreted as an internal and external impulse in a person that is indicated by the desire and interest to carry out activities, hopes and ideals, appreciation, and respect for oneself, a good environment, and interesting activities. The theory of Miao et al which divides motivation into four indicators, namely, challenge orientation, task enjoyment, compensation and recognition orientation.

\section{Conceptual Framework}

Based on the background and the theoretical study above, the researcher described the research conceptual framework as follows:

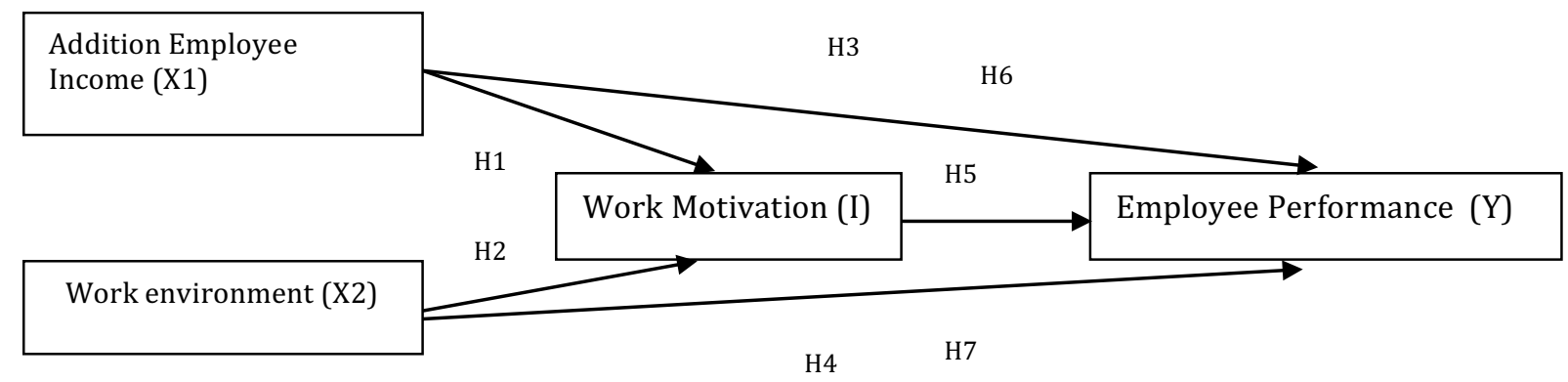

Figure 1: Conceptual Framework

Based on the conceptual framework above, the hypothesis can be formulated in this study as follows:

$\mathbf{H}_{\mathbf{1}}=$ Be expected there is a positive and significant effect of Additional Employee Income on Work Motivation

$\mathbf{H}_{2}=$ Be expected there is a positive and significant influence of the Work Environment on Work Motivation

$\mathbf{H}_{3}=$ Be expected there is a positive and significant effect of Additional Employee Income Against Employee Performance

$\mathbf{H}_{4}=$ Be expected there is a positive and significant influence on the Work Environment on Employee Performance

$\mathbf{H}_{5}=$ Be expected there is a positive and significant influence of Work Motivation on Employee Performance

$\mathbf{H}_{\mathbf{6}}=$ Be expected there is a positive and significant effect of Additional Employee Income Against Work Motivation and Its Impact on Employee Performance

$\mathbf{H}_{7}=$ Be expected there is a positive and significant influence on the Work Environment on Work Motivation and Its Impact on Employee Performance 


\section{RESEARCH METHOD}

This study uses quantitative methods with path analysis. The research variables are Additional Employee Income (AEI), work environment, work motivation and employee performance. The population is 129 employees of the public works and spatial planning Office of Padang city but who were sampled only 98 employees after using the Slovin formula. The data analysis technique used is path analysis. Where the path analysis is as follows:

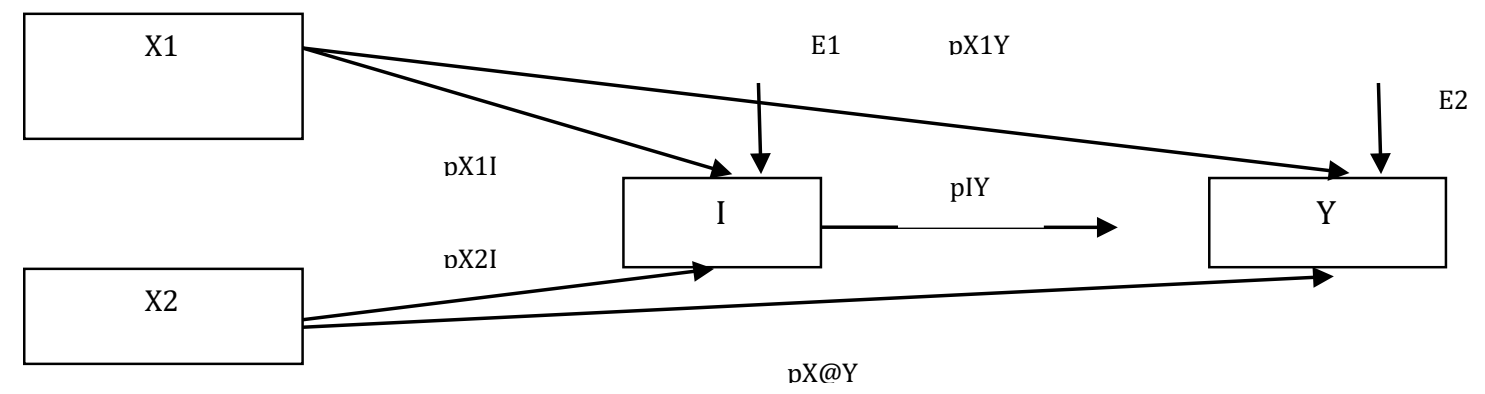

Figure 2: Path Analysis

\section{Path Analysis}

\section{ANALYSIS AND RESULTS}

\section{a. Path Coefficient of Model I}

Multiple linear regression analysis was used in this study with the aim to determine whether there is an influence of independent variables on the dependent variable. The statistical calculation in multiple linear regression analysis used in this study is to use the IBM SPSS computer program version 21.0. The summary of the results of data processing using the SPSS program are as follows:

Table 1

Regression Effect of Additional Employee Income and Work Environment on Work Motivation Coefficients ${ }^{a}$

\begin{tabular}{|c|c|c|c|c|c|}
\hline \multirow[t]{2}{*}{ Model } & \multicolumn{2}{|c|}{$\begin{array}{c}\text { Unstandardized } \\
\text { Coefficients }\end{array}$} & \multirow{2}{*}{\begin{tabular}{|c|}
$\begin{array}{c}\text { Standardized } \\
\text { Coefficients }\end{array}$ \\
Beta
\end{tabular}} & \multirow[t]{2}{*}{$\mathrm{t}$} & \multirow[t]{2}{*}{ Sig. } \\
\hline & B & $\begin{array}{l}\text { Std. } \\
\text { Error }\end{array}$ & & & \\
\hline (Constant) & 9,838 & 4,345 & & 2,264 & ,026 \\
\hline $1 \quad$ Addition Employee Income & ,304 & ,108 & ,249 & 2,828 & ,006 \\
\hline Work Environment & ,483 & ,093 & 457 & 5,188 & 000 \\
\hline
\end{tabular}

a. Dependent Variable: work motivation

Based on the table above, it was found that the significance value of the additional employee income variable $(\mathrm{X} 1)=0.006<0.05$, this means that additional employee income (X1) had a significant effect on work motivation (X3). While the work environment variable (X2) $=0,000$ $<0,05$ which means the work environment (X2) has a significant effect on work motivation (X3). 
Table 2

R Square X3 (Motivasi) Value

Model Summary

\begin{tabular}{|l|r|r|r|r|}
\hline Model & R & R Square & $\begin{array}{c}\text { Adjusted R } \\
\text { Square }\end{array}$ & $\begin{array}{r}\text { Std. Error of } \\
\text { the Estimate }\end{array}$ \\
\hline 1 &, $588^{\mathrm{a}}$ &, 346 &, 332 & 4,649 \\
\hline
\end{tabular}

a. Predictors: (Constant), work environment, addition employee income

While the value of $\mathrm{R}^{2}$ ( $\mathrm{R}$ Square) contained in the Model Summary table is 0.346 which gives the meaning that the contribution of variables X1 and X2 to X3 is 34.6\% and the remaining $65.4 \%$ is the contribution of other variables not included in research. Based on the results above, the structural equation is obtained:

$$
Y=0,249 \cdot X_{1}+0,457 \cdot X_{2}
$$

From the processing of the data above, we can obtain the Model I Path Diagram, as follows:

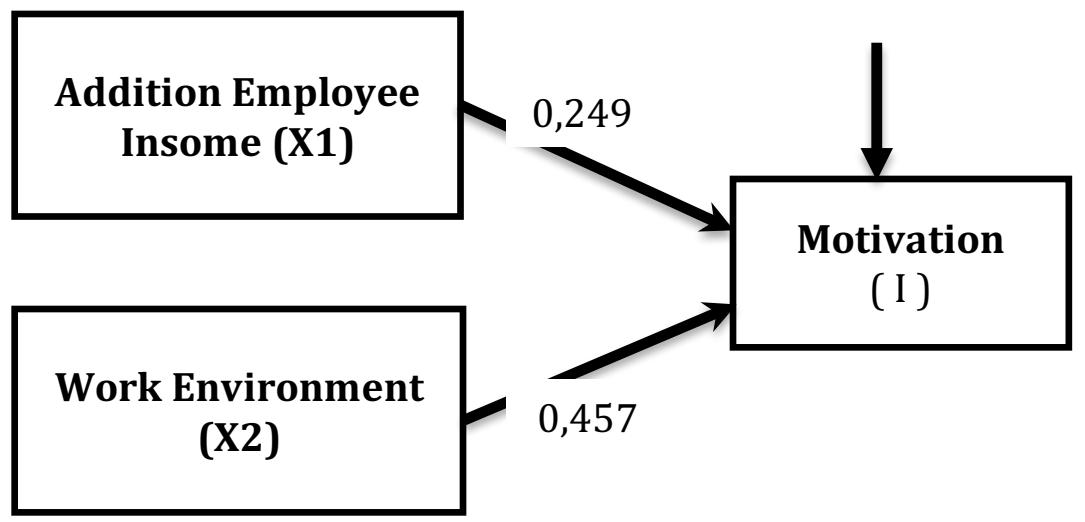

Figure 3: Model I - Path Analysis

\section{b. Path Coefficient of Model II}

Multiple linear regression analysis is still used in subsequent studies to obtain the two model path coefficients. This is to find out whether there is an influence of independent variables (additional income for employees and the work environment) and intervening variables (work motivation) on the dependent variable (employee performance). Can be seen in the table below: 
Table 2

Regression Effect of Additional Employee Income, Work Environment, Work Motivation on Employee Performance

Coefficients $^{\mathrm{a}}$

\begin{tabular}{|c|c|c|c|c|c|}
\hline \multirow[t]{2}{*}{ Model } & \multicolumn{2}{|c|}{$\begin{array}{l}\text { Unstandardized } \\
\text { Coefficients }\end{array}$} & $\begin{array}{c}\text { Standardized } \\
\text { Coefficients }\end{array}$ & \multirow[t]{2}{*}{$\mathrm{T}$} & \multirow[t]{2}{*}{ Sig. } \\
\hline & B & $\begin{array}{l}\text { Std. } \\
\text { Error }\end{array}$ & Beta & & \\
\hline (Constant) & 17,009 & 4,769 & & 3,567 & 001 \\
\hline $\begin{array}{l}\text { Addition employee } \\
\text { income }\end{array}$ & ,121 & , 120 & 101 & 1,008 & 316 \\
\hline Work environment & ,172 & ,113 & , 166 & 1,527 & 130 \\
\hline Work motivation & ,308 & 110 & 315 & 2,812 & 006 \\
\hline
\end{tabular}

a. Dependent Variable: employee performance

\section{Source: SPSS data processing}

Based on the table above, it was found that the significance value of the three variables, namely additional employee income $(\mathrm{X} 1)=0.316>0.05$. This means that additional employee income (X1) does not have a significant effect on employee performance (Y). While the work environment variable $(\mathrm{X} 2)=0.130>0.05$ which means the work environment $(\mathrm{X} 2)$ does not significantly influence employee performance (Y). And for work motivation variables (X3) = $0.006<0.05$ which means that it has a significant effect on employee performance (Y).

Table 3

R Square Z (Performance) Results Model Summary

\begin{tabular}{|l|r|r|r|r|}
\hline Model & \multicolumn{1}{|c|}{$\mathrm{R}$} & R Square & $\begin{array}{c}\text { Adjusted R } \\
\text { Square }\end{array}$ & $\begin{array}{c}\text { Std. Error of } \\
\text { the Estimate }\end{array}$ \\
\hline 1 &, $479 \mathrm{a}$ &, 230 &, 205 & 4,970 \\
\hline
\end{tabular}

a. Predictors: (Constant), work motivation, addition employee income, work environment

For the value of $R^{2}$ (R Square) found in the model summary table is 0.230 which gives the meaning that the contribution of variables $\mathrm{X} 1, \mathrm{X} 2$ and $\mathrm{X} 3$ to $\mathrm{Y}$ is $23.0 \%$ and the remaining $77.0 \%$ is the contribution of other variables not included in the study.

$$
Y=0,131 \cdot X_{1}+0,166 \cdot X_{2}+0,315 . Y
$$


From the processing of the data above, It can be obtained path chart of model II, as follows:

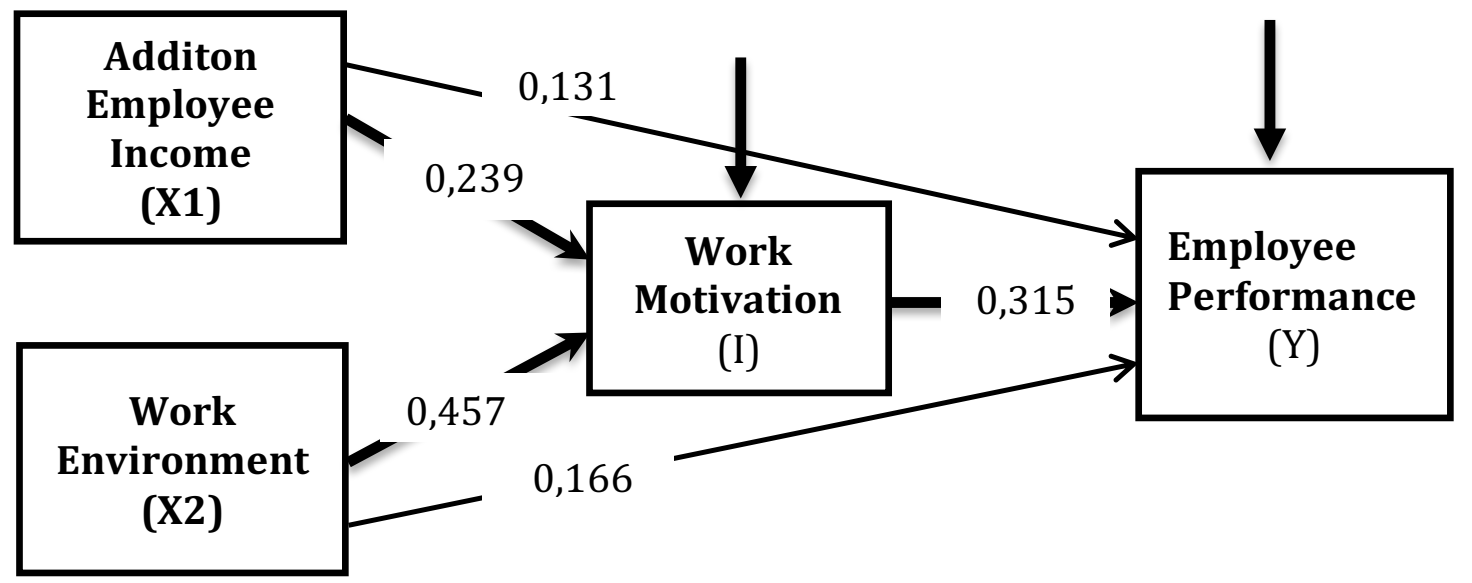

Figure 4 Model II - Path Analysis

\section{Coefficient of Determination and Test the Hypothesis}

\section{a. Coefficient of Determination $\left(R^{2}\right)$}

In multiple linear tests, the coefficient of determination is used to determine the percentage contribution of the simultaneous influence of independent variables on the dependent variable for which the numbers in the model summary table are used. How to determine the Determination Coefficient by looking at column $\mathrm{R}^{2}$, the result of SPPS data analysis. $\mathrm{R}^{2}$ test or determination test is an important measure in regression, because it can inform whether or not the estimated regression model, or in other words, it can measure how closely the regression line is estimated by the actual data. The coefficient of determination $\left(R^{2}\right)$ reflects how much variation of the dependent variable $\mathrm{Y}$ can be explained by the independent variable $\mathrm{X}$. Adjusted $\mathrm{R}$ square is $\mathrm{R}$ square which has been adjusted This value is always smaller than $\mathrm{R}$ square of this number can have a negative price, that for regression with more than two independent variables used adjusted $\mathrm{R}^{2}$ as the coefficient of determination. The results of testing the coefficient of determination for the effect of additional variables on employee income and work environment on work motivation can be seen in the following table 4:

Table 4

Determination Coefficient Equation 1

\begin{tabular}{|c|c|c|}
\hline R & R Square & Adjusted R Square \\
\hline, $588^{\mathrm{a}}$ &, 346 &, 332 \\
\hline
\end{tabular}

Variabel: work environment and addition employee income

Source: results of data processing

Based on table 4 above, it can be seen that the Adjusted R Square value is 0.332 , which means that the additional variables of employee income and work environment on work motivation have an influence of $33.2 \%$ while the remaining $66.8 \%$ is influenced by other variables not examined.

Whereas for the influence of additional variable employee income, work environment and work motivation on employee performance can be seen in the following table 5: 
Table 5

Determination Coefficient Equation 2

\begin{tabular}{|c|c|c|}
\hline $\mathbf{R}$ & R Square & Adjusted R Square \\
\hline, $479^{\mathrm{a}}$ &, 230 &, 205 \\
\hline
\end{tabular}

Variabel: work motivation, addition employee income and work environment

Sumber: results of data processing

Based on table 5 above, it can be seen that the Adjusted R Square value is 0.205 , which means that the variable additional employee income, work environment and work motivation on employee performance has an influence of $20.5 \%$ while the remaining $79.5 \%$ is influenced by other variables not examined.

\section{b. F test}

Testing the hypothesis by using the $\mathrm{F}$ test is done to determine whether the research model is feasible or not feasible to study. Then through testing hypotheses using SPSS 21 the results obtained as in Table 6 below are for additional employee income variables and work environment for work motivation.

Table 6

Anova Equation 1

\begin{tabular}{|c|c|c|}
\hline Model & F & Sig. \\
\hline Regression & 25,147 &, 000 \\
\hline
\end{tabular}

Dependent Variabel: work motivation

Source: results of data processing

From Table 6, it can be seen that the result of $\mathrm{F}$ count is 25,147 which is significant at the level of 0,000 . Whereas for additional employee income variables, work environment and work motivation on employee performance can be seen in table 4.27 below:

Table 7

Equation Anova 2

\begin{tabular}{|c|c|c|}
\hline Model & F & Sig. \\
\hline Regression & 9,354 &, 000 \\
\hline
\end{tabular}

Dependent Variabel: employee performance

Source: results of data processing

From table 7, it can be seen that the result of $\mathrm{F}$ count is 9.335 which is significant at the level of 0.000. Then it can be concluded from the two results of the $f$ test above that this research model is feasible to do.

\section{DISCUSSION}

This discussion is based on the results of research obtained from the field and data analysis carried out as well as from the results of the study. The purpose of this discussion is to explain and interpret the results obtained. Additional variables of employee income and work environment on work motivation and their impact on employee performance. Then the regression analysis is calculated to see the effect of independent variables on the dependent variable.

\section{Effect of Additional Employee Income on work motivation}

Based on the results of data processing and hypothesis testing it can be seen that there is a positive and significant effect of Additional Employee Income on Work Motivation in the Public 
Works and Spatial Planning Service of Padang City. Thus the first hypothesis which states that there is a positive and significant effect of Additional Employee Income Against Motivation can be accepted because it is in accordance with the results of the study.

Where the presence of additional employee income provided by the government to the employee work unit that has been set in the regulation will lead to higher morale or work motivation provided by the employee for the success of the organization. This result is in accordance with the research conducted by Dyah Latu, et al (2016) showing that the additional income of employees has a positive and significant effect on work motivation at the Temanggung District Health Service.

\section{Effect of Work Environment on Work Motivation}

Based on the results of data processing and hypothesis testing it can be seen that there is a positive and significant influence of the Work Environment on Work Motivation in the Public Works and Spatial Planning Service of Padang City. Thus the first hypothesis which states that there is a positive and significant influence on the Work Environment on Motivation can be accepted because it is in accordance with the results of the study.

Where by being in a good work environment employees to carry out their activities can increase morale or better work motivation for the success of the organization. These results are consistent with the research conducted by Dyah Latu, et al (2016) showing the results of the work environment have a positive and significant effect on work motivation at the Temanggung District Health Service.

\section{Effect of Additional Employee Income Against Employee Performance}

Based on the results of data processing and hypothesis testing, it can be seen that there is a positive and insignificant influence on Additional Employee Income on employee performance at the Public Works and Spatial Planning Service of Padang City. Thus the first hypothesis which states that there is a positive and significant effect of Additional Employee Income Against Motivation is not acceptable because it is not in accordance with the results of the study.

Where it should be with the additional income of employees provided by the government to the employee work units that have been set in the regulations would certainly improve employee performance that would be provided by employees for the success of the organization. This result is not in accordance with the research conducted by Dyah Latu, et al (2016) showing that the additional income of employees has a positive and significant effect on the performance of employees at the Temanggung District Health Service.

\section{Effect of Work Environment on Employee Performance}

Based on the results of data processing and hypothesis testing it can be seen that there is a positive and insignificant influence of the Work Environment on Employee Performance at the Public Works Service and the City Spatial Planning of Padang. Thus the first hypothesis which states that there is a positive and significant influence on the Work Environment on Employee Performance is not acceptable because it is not in accordance with the results of the study.

Where should be in a good work environment of course employees to carry out their activities can improve better performance for the success of the organization. But in this study the environment was influential but not significant, this is consistent with the research conducted by Dyah Latu, et al (2016) showing the results of the work environment did not have a positive 
and significant effect on the performance of employees at the Temanggung District Health Service.

\section{Effect of Work Motivation on Employee Performance}

Based on the results of data processing and hypothesis testing it can be seen that there is a positive and significant effect of Work Motivation on Employee Performance at the Public Works and Spatial Planning Service of Padang City. Thus the first hypothesis which states that there is a positive and significant effect of Work Motivation on Employee Performance is acceptable because it is in accordance with the results of the study.

Where by getting good work motivation employees in carrying out their activities can improve employee performance better for organizational success. These results are in accordance with the research conducted by Dyah Latu, et al (2016) showing the results of work motivation have a positive and significant effect on the performance of employees at the Temanggung District Health Service.

\section{Effect of Additional Employee Income on Work Motivation and Its Impact on Employee Performance}

Based on Government Regulation No. 58 of 2005 concerning Regional Financial Management in the explanation of article 63, it states, "Additional income is provided in the context of improving employee welfare based on work performance, place of duty, working conditions and professional scarcity". With this regulation, employees are expected to be more motivated and can improve their performance. In this study based on the results of the path analysis test (Path Analysis), it can be seen that the Additional Employee Income has a positive and significant effect on Work Motivation but subsequently has a positive but not significant impact on Employee Performance. This result is in accordance with the research conducted by Dyah Latu et al (2016) which shows the results of research that Additional Employee Income has a positive and significant effect on work motivation but subsequently has no impact on the performance of Temanggung District Health Service staff.

\section{Effect of Work Environment on Work Motivation and Its Impact on Employee Performance}

With the existence of a good and conducive work environment and having adequate equipment, of course employees can also be motivated to work better and improve the performance of the employees themselves. Based on the results of the research conducted, the results obtained from the Work Environment have a positive and significant effect on Work Motivation and have a positive but not significant impact on Employee Performance. These results are not in accordance with the study of Dyah Latu et al (2016) showing the results of the work environment have a positive and significant effect on work motivation and also have an impact on the performance of the employees of the Temanggung District Health Service.

\section{Conclusions}

\section{CONCLUSIONS AND SUGGESTIONS}

Based on the results of research and data processing that has been done to determine the analysis of the factors that influence the performance of employees of the public works and spatial planning office of Padang city, the following conclusions can be drawn:

1. There is a positive and significant effect of additional employee income against work motivation. This happens because the provision of additional income for employees can increase the motivation of employees in carrying out their activities, where this result is achieved because the level of achievement of respondents is quite good at $70.08 \%$. 
2. There is a positive and significant influence on the work environment on work motivation. This happens because employees are in a safe and conducive work environment that can increase the motivation of employees in carrying out their activities, where this result is achieved because the level of achievement of respondents is quite good at $79.90 \%$.

3. There is a positive and insignificant influence on additional employee income against employee performance. This happens because the provision of additional employee income is determined from the assessment of employee performance carried out by superiors and examined by a team that has been appointed by the government, but the results may not be maximal, this result may also influence the level of achievement of respondents that is quite good at $70.08 \%$

4. There is a positive and insignificant influence on the work environment on employee performance. This happens because in a work environment that is less effective in carrying out the task will reduce the performance of employees in their work. this result might also influence the level of achievement of respondents which is quite good at $79.90 \%$

5. There is a positive and significant effect of work motivation on employee performance. This happens because employees get very good work motivation so that they can improve employee performance in carrying out their activities, where this result is achieved because the level of achievement of respondents is good at $80.01 \%$ and employee performance $81.45 \%$.

6. There is a positive and significant effect of additional employee income against work motivation and has no impact on employee performance. This happens because the provision of additional income for employees can certainly increase the motivation of employees in carrying out their activities, where this result is achieved because the level of achievement of respondents is quite good at 70.08\%. However, it does not have an impact on the performance of its employees because in evaluating employee performance carried out by superiors and examined by a team that has been appointed by the government, the results have not been maximized.

7. There is a positive and significant influence on the work environment on work motivation and does not have an impact on employee performance. This happens because employees are in a safe and conducive work environment that can increase the motivation of employees in carrying out their activities, where this result is achieved because the level of achievement of respondents is quite good at 79.90\%. But it does not have an impact on employee performance because the work environment in practice is not conducive or less effective for carrying out tasks, this will reduce employee performance in their work.

\section{Suggestions}

In this study the use of samples was limited to 1 agency, namely the public works office and spatial planning of Padang city, so it is expected that in future studies to:

1. Adding the number of samples that will be used in the next study so that it can produce better research results because the sample of this study is only in one agency in the city of Padang. It is expected that the next researcher can use a sample of more than one agency.

2. Increase the number of variables that can affect the dependent variable, especially employee performance variables

\section{Reference}

D Latu.N, Rubyah Hutomo dan Ahmad Mansyur. 2016. Pengaruh Tambahan Penghasilan Pegawai dan Lingkungan Kerja Terhadap Motivasi Kerja Serta Dampaknya Pada Kinerja Pegawai Dinas Kesehatan Kabupaten Temanggung. http://stiepari.greenfrogts.co.id/jurnal/index.php/JVM/article/view/50

Dhermawan, A. A. N. B., Sudibya, I. G. A., \& Utama, I. W. M. (2012). Pengaruh Motivasi, Lingkungan Kerja, Kompetensi, Dan Kompensasi Terhadap Kepuasan Kerja Dan Kinerja Pegawai Di Lingkungan Kantor Dinas 
Pekerjaan Umum. Jurnal Manajemen, Strategi Bisnis, Dan Kewirausahaan, 6(2), 173-184. Retrieved from https://ojs.unud.ac.id/index.php/jmbk/article/view/2203

Mangkunegara, Anwar Prabu. 2005. Evaluasi Kinerja SDM. Bandung: Refika Aditama.

M. Madjid. 2016. Pengaruh Tambahan Penghasilan Pegawai (TPP) dan Kemampuan Kerja Terhadap Kinerja Pegawai Pada Badan Perencanaan, Penelitian dan Pembangunan Daerah (BAPPEDA) Kabupaten Morowali

Peraturan Menteri Dalam Negeri No. 13 tahun 2006 tentang Pedoman Pengelolaan Keuangan Daerah.

Peraturan Pemerintah No. 58 tahun 2005 tentang Pengelolaan Keuangan Daerah.

Peraturan Walikota Padang Nomor 01 Tahun 2018 tentang Besaran Tambahan Penghasilan bagi Pegawai Negeri Sipil di Lingkungan Pemerintahan Kota Padang.

Saroinsong, S. (2014). Pengaruh Tunjangan Tambahan Penghasilan (TTP) Terhadap Kinerja Pegawai Negeri Sipil (PNS) Di Sekretariat Dewan Perwakilan Rakyat Daerah Kota Tomohon. Jurnal Manajemen Dan Bisnis, 2(2).

Tampi, B. J. (2014). Pengaruh Gaya Kepemimpinan dan Motivasi Terhadap Kinerja Karyawan Pada PT. Bank Negara Iindonesia, TBK (Regional Sales Manado). Jurnal "Acta Diurna" Volume III. No.4., III(4), 1-20. 